\title{
MADRINAS DE LECTURA
}

\author{
Gabriela Mistral (1926)
}

Del Consejo Nacional de Mujeres de Buenos Aires — hermosa institución- esta noticia que beneficiará a otras.

La sección más fuerte del Consejo es la Biblioteca, y la Biblioteca viva, es decir, con el libro movedizo y fecundo, bien distribuido, accesible y variado. Las iniciativas de la Biblioteca son numerosas, pero la que anoto me parece la más original.

La Argentina mira mucho hacia la civilización rural, porque las fuentes de su economía son, como se sabe, rurales. No hay cultura campesina sin buen maestro. El pobre hombre o la pobre mujer, a la par sin cultura general y sin instrucción agrícola, que en Chile se mandan al campo, no pueden sacar a las aldeas de eso que podríamos llamar su masa-barbarie. No llevan lo mejor de las ciudades y no aman tampoco la vida del campo.

Para hacer llegar a la estancia (hacienda) del último pedazo de la Patagonia o del Chaco el latido de Buenos Aires, el Consejo que menciono ha creado las "madrinas de lectura". Parece que la institución es nueva en América.

Las esposas de los terratenientes, las profesoras de Normal, las periodistas, etc., en una alta cifra, se inscriben contrayendo la obligación de tomar a cargo la lectura de una maestra rural. La labor es desinteresada: no se trata de mandar ni la biblioteca oficial del Sindicato Rojo ni la del Sindicato Azul. Libros de divulgación pedagógica, de geografía recreativa, revistas de agricultura, lo mejor del género biográfico universal, periódicos de labores de mano, también las excelentes ediciones dominicales de los grandes cotidianos, todo eso va, volumen a volumen, en encomienda quincenal. Entiendo que no hay devolución; no soy partidaria del libro alquilado. Ruskin decía que todo individuo decente debía tener los mejores libros; pero incorporados al menaje de su casa y de su espíritu. El libro que se ama no puede ser sino lo que el vestido o el lecho: decorosa propiedad.

Naturalmente, la "ahijada de lectura" tiene derecho a solicitar de su madrina desconocida las obras que le interesan particularmente. De tan sencillo modo puede cumplir una mujer con algo que me ha parecido siempre que debía ser profesión humana: la de formar una criatura espiritual...

La llamada vida del campo es muy noble para ser vivida por aquellos que han tenido ya largo sustento de cultura en las ciudades: llevan los materiales para hacer en la soledad la más poderosa vida mental y la depuración más segura de sus facultades. Para la inteligencia sin pasión de estudio, para el alma nueva que debe construirse, el campo es una fatalidad. Después de tres años se siente en estas últimas la herrumbre, la ociosidad hecha naturaleza. ¿Qué hace en el silencio el que no ha llevado pensamientos que esmerilar y qué hace con la soledad el que no sabe cuajarse sus entrañas de amigos? 
Yo estoy entre los que conocen esa guardia de sí mismo que es necesario hacerse en el campo, para no caer en la modorra ni en el desfallecimiento, vigilancia para darse cuenta de cuándo la tristeza se hace amodorramiento, de cuándo la tensión se vuelve febril y de cuándo el monólogo, que parece tan peligroso a Eugenio d’Ors, empieza a volverse soberbia.

Y por conocer yo hasta el último límite el abandono en el campo, me ha conmovido la obra de estas grandes mujeres argentinas. Tienen ojo pronto para ver las fallas, los huecos de la organización de la enseñanza. Ayudan finalmente al Estado que, al cabo, es una máquina brutal a la que no puede pedírsele todo.

Merece mención especial entre ellas la hacendada. Lo malo de nuestros ricos está en que casi nunca saben ser dueños. Cosa compleja ha sido siempre eso, sobre todo ser dueño de la tierra. Porque la tierra contiene al hombre, y regir pastales y viñas es cargar también con las almas que se mueven entre ellos. No hay criatura más abandonada en tierra de Chile que la campesina. El dueño de industrias tiene menos angustiosas responsabilidades: la ciudad le ayuda a formar moralmente al obrero: le ayudan el teatro, la escuela nocturna, la conferencia, hasta la calle. El terrateniente tiene él solo que responder de sus campesinos. En muchas regiones éste es un subhombre que no ha nacido todavía para la realidad espiritual.

Estará bien que el hacendado descanse su conciencia en el maestro de escuela, pero antes hay que construir al maestro rural.

Es necesario civilizar, cristianizar el campo. Siquiera desbarbarizarlo.

21 de marzo de 1926, en Magisterio y Niño 